\title{
The Beginning of Congress Poland in the Discourse of the French Press
}

\author{
M. S. Belousov, A.S. Belousov
}

For citation: Belousov M.S., Belousov A.S. The Beginning of Congress Poland in the Discourse of the French Press. Vestnik of Saint Petersburg University. History, 2019, vol. 64, iss. 4, pp.1195-1212. https://doi.org/10.21638/11701/spbu02.2019.402 (In Russian)

The article focuses on the formation of the Polish-Lithuanian discourse by the French press and its interpretation by Russian intellectuals in 1815-1825. The image of Alexander I and his policy towards Congress Poland obviously underwent a complex transformation. French publicists rejoiced at the decisions of the Congress of Vienna and the declaration of constitution on the affiliated territories. The press articulated a liberator-tsar discourse: Alexander did not defeat Napoleon to become a new Napoleon himself. He only cared about the well-being of his new subjects: due to the Russian Emperor the Poles received long-awaited freedom embodied in the constitution. The French press featured Alexander I not only as a liberator-tsar, but as a ruler guided by a national idea about national interests. Praising its new idol the French press managed to convince Russian and Polish public of their protagonist's polonophilia. This gave rise to debates among the intellectuals, who mostly thought negatively of Alexander's intentions. Concerns intensified after his famous Warsaw Speech. However, in 1820, the Emperor's interest in the Polish-Lithuanian affairs subsided, with the policy towards them becoming more conservative. Eventually, French newspapers reverted to the discourse of an uncivilized eastern neighbor. Thus, the image of a liberator-tsar gave way to that of a cruel despot and usurper eager to subdue European territories. The rhetoric of liberal publicists found some support in the Russian society, but mostly it contributed to the growth of Anti-Polish sentiments. The same dialectic unity and clash of opinions, articulated both due to the French Journalism and contrary to it, is found in the Decembrist milieu.

Keywords: Alexander I, Congress Poland, constitution, French press, Decembrists.

Mikhail S. Belousov - PhD in History, Associate Professor, St. Petersburg State University, 7-9, Universitetskaya nab., St. Petersburg, 199034, Russian Federation; m.belousov@spbu.ru

Alexander S. Belousov - Research fellow, St. Petersburg State University, 7-9, Universitetskaya nab., St. Petersburg, 199034, Russian Federation; belousov1504@gmail.com

Михаил Сергеевич Белоусов - канд. ист. наук, доцент, Санкт-Петербургский государственный университет, Российская Федерация, 199034, Санкт-Петербург, Университетская наб., 7-9; m.belousov@spbu.ru

Александр Сергеевич Белоусов - мл. науч. сотр., Санкт-Петербургский государственный университет, Российская Федерация, 199034, Санкт-Петербург, Университетская наб., 7-9; belousov1504@gmail.com

This research was supported by the grant No. 19-18-00073 "National Identity in the Imperial Politics of Memory: History of The Grand Duchy of Lithuania and the Polish-Lithuanian State in Historiography and Social Thought of the $19^{\text {th }}-20^{\text {th }}$ Centuries" of the Russian Science Foundation.

Исследование выполнено в рамках гранта № 19-18-00073 «Национальная идентичность в имперской политике памяти: история Великого княжества Литовского и Польско-Литовского государства в историографии и общественной мысли XIX-XX вв.» Российского научного фонда.

(c) Санкт-Петербургский государственный университет, 2019 


\title{
Начальные страницы истории Царства Польского в дискурсе французской прессы
}

\author{
М. С. Белоусов, А. С. Белоусов
}

Для цитирования: Belousov M. S., Belousov A. S. The Beginning of Congress Poland in the Discourse of the French Press // Вестник Санкт-Петербургского университета. История. 2019. Т. 64. Вып. 4. C. 1195-1212. https://doi.org/10.21638/11701/spbu02.2019.402

Предлагаемая статья посвящена процессу формирования французскими средствами массовой информации дискурса по польско-литовской проблематике и его восприятию российскими интеллектуалами в 1815-1825 гг. Показано, что образ императора Александра I, как и его политика по отношению к Царству Польскому, претерпел сложную трансформацию. Решения Венского конгресса и провозглашение конституции на присоединенных территориях вызвали восторг в среде французских публицистов. Пресса артикулировала дискурс царя-освободителя: Александр I разгромил Наполеона не для того, чтобы стать новым Наполеоном. Его единственным устремлением было благоденствие его новых подданных: поляки наконец-то получали желанную свободу в виде собственной конституции именно благодаря российскому императору. Усилиями французской прессы Александр I представал не просто государем-освободителем, а правителем, действующим согласно национальным представлениям о национальных интересах. Французская пресса, восхваляя своего нового кумира, оказалась настолько убедительной, что заставила поверить в полонофилию своего протагониста даже представителей российского и польского обществ. Это породило дискуссии в среде интеллектуалов, большинство из которых отрицательно воспринимали интенции императора. Но обсуждение этого сюжета шло в категориях и на языке французских публицистов. Опасения еще больше усилились после знаменитой Варшавской речи Александра I. Но в 1820 г. его интерес к польско-литовским делам начинает ослабевать, курс становится более консервативным. В результате французские газеты вернулись к дискурсу о варварском восточном соседе. Так царь-освободитель превратился в жестокого деспота и узурпатора, стремящегося воспользоваться любой возможностью для подчинения европейских территорий. Риторика либеральных публицистов нашла своих сторонников и в российском обществе. Но в большей степени она способствовала усилению антипольских настроений. Именно такую диалектическую борьбу и единство мнений, сформированных благодаря или вопреки французской публицистике, мы находим в среде декабристов.

Ключевые слова: Александр I, Царство Польское, конституция, французская пресса, декабристы.

The Great French Revolution destroyed the familiar world order and perception of reality. The "age of liberalism" began". The rise and wide spread of new methods of communication in the society result in the collapse of the hegemony of the state in shaping the information field as well as in thinking and behavioral patterns. The press plays a key role here: the publicists, following J.P. Marat, started orchestrating the political process. A proposition of M. Burckhardt that "the media produce the ideas they later use to convey" enables us to take a firm epistemological stand, namely, that the media do not supplement

1 Wallerstein I. Posle liberalizma. Moscow, 2003.

2 Burckhardt M. Vom Geist der Maschine. Eine Geschichte kultureller Umbrüche. Frankfurt; New York, 1999. S. 67. 
or compensate anything, but create a new world - the reality of the media ${ }^{3}$. Journalists create discourses which later on determine the "superstructure" 4

The emergence of printed materials brought the discussions, which had previously been circulating only within the state institutions or among the representatives of the political elites, into the public sphere. F. R. Chateaubriand, a famous French publicist and statesman, wrote: "The press is a new element, an unprecedented force, which has rushed in to this world recently; it is a new word which turned into lightning, social electricity. Do we have the power to destroy it? The more we suppress it, the sooner the outburst will happen. Hence, you have to come to terms with the press, as you did with the steam engine" 5 . Serving as translators of various concepts and thinking patterns, mass media create some entirely new ideological concepts which become intertwined and generate new subjective ideas of the reality. That is why the era of Biedermeire - the period of the formation of the new political thinking - when the old methods of the assertion of one's right to play the role in the public politics represented by meritocracy give way to the new ones based on bourgeois virtues ${ }^{6}$, - was defined by M. Foucault as the time of the transition to Contemporaneity marked by the change of the discursive framework of subjectivity construction ${ }^{7}$.

In this context, the issue of the integration and circulation of new ideas in Russia at that time is extremely topical. In particular, the Polish-Lithuanian problems, which were of great importance to the real politics of Russia after the era of Napoleonic wars, should be singled out. It was aptly pointed out by one of the articles in Le Courier Français in an obituary to Alexander I: "The Emperor used to drift from one passion to another, from one cult to another. From 1803 to 1807 he adhered to the cult of Catherine II and her governing methods, rejected by Paul I; from 1807 to 1811 he was enthusing over the cult of Napoleon, his glory and his aggressive ideas; from 1812 to 1815 he together with the Spanish Cortes, German students, Polish sejms and French constitutionalists kept to the principles of liberalism, which is obvious from his proclamation to the peoples of Europe;

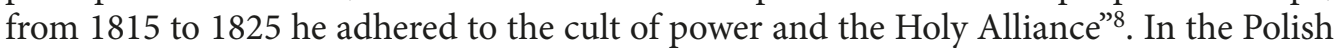
affairs all these issues were intertwined, including the testing of the constitutional experience and the relationship with the Holy Alliance.

French periodicals, which shaped the reaction of the society to different news both in France and other European countries, were the main source of political discourse with regard to the Polish-Lithuanian territories. In the first place these were two mass-circulation news-papers: Le Journal des Débats and Le Constitutionnel. They both had distinct ideological orientation. The first one held royalist views and supported F. R. Chateaubriand. The second one comprised mostly liberal materials ${ }^{9}$. At the same time, in addition to their own sources, the editors actively used to draw information from the European periodical press. The Journal de Frankfurt, which became one of the key sources of information

${ }^{3}$ Stepanov M. A. Apparatnoe ponimanie media // Vestnik Leningradskogo gosudarstvennogo universiteta im. A. S. Pushkina. 2010. Vol. 2, iss. 3. P. 195.

${ }^{4}$ Laclau E., Mouffe Ch. Hegemony and socialist strategy. London; New York, 2001.

${ }^{5}$ Chateaubriand F.-R. Zamogil'nye zapiski. Moscow, 1995. P. 401-402.

${ }^{6}$ Caton A. Th. Disenchantment during the Biedermeire period: political subtexts in Schubert's songs: PhD Thesis. Cardiff, 2011. P. III-V, 23-26.

7 Foucault $M$. Intellektualy i vlast': Izbrannye politicheskie stat'i, vystupleniia i interv'iu. Moscow, 2002. P. 343-347.

${ }^{8}$ Cit. by: Viazemskii P. A. Zapisnye knizhki. Moscow, 1963. P. 124.

9 Angran P. Otgoloski vosstaniia dekabristov vo Frantsii // Voprosy istorii. 1952. No. 12. P.98-116. 
about the Polish affairs in the early years of the existence of Congress Poland, especially for the Le Constitutionnel, can serve as an example of this. News items were printed and reprinted from other sources almost without comments, in accordance with the French tradition of public communication. However, the usage of certain adjectives enables to define the attitude of the editors towards the news they published.

It is noteworthy that both periodicals in the headlines and titles for the news columns referred to the Polish-Lithuanian territories as "Poland", bearing in mind both a big historic-geographical unit and a certain state entity. This was of vital importance to the political discourse of Europe as Poland was not fully identified with Russia and was deemed its equal in the titles of the news columns. Such appellations as the "Kingdom of Poland", "Russian Poland", "old Poland", "Great Poland", and "Lithuania" were used only in the texts of the news items. The full-text content-analysis of the periodicals focused on the Polish-Lithuanian issues provides an opportunity to throw light on the relationship of Russia with the French public in this context, and also to assess the relevance and significance of this topic to Europe. Such analysis is necessary in the light of the absence in Russia of independent press (like in England or France) and the institution of public debates; this fact resulted in Russian public drawing on European media sources for information. The information published in European newspapers was usually discussed in salons and ball rooms. The newspapers of Western Europe not only served as the main source of information about the events in Europe ${ }^{10}$ but also provided instruction in the field of models of political behavior. This can be confirmed by the conclusions of numerous researchers: the influence of Parisian periodicals was so strong that it gave good grounds for thinking about the "French colonization" of Europe with regard to the history of ideas. The political thinking of Russian elites was shaped through the European press - it acquainted the gentry with the culture of discussion and popularized different political views ${ }^{11}$.

Not for nothing did the French press take such a great interest in the Polish affairs: the lots of both countries had been closely intertwined for a long time. Back in the $18^{\text {th }}$ century the French royal court exerted great influence on Rzeczpospolita and made it part of its foreign policy construct against the young Russian Empire, called the "Eastern barrier". It was also the revolutionary France where the Polish emigrants, who had fled the country after its third partition, found refuge. They deeply integrated into the French society and even established Polish legions as part of the Napoleonic army. Since the capture of Paris the French public had been deeply concerned about the Polish scenario being mirrored in their country as well. The "secret note", compiled by Baron de Vitrolles, in the presence of Count d'Artois, J. B. Villele and F. R. Chateaubriand and later on delivered to the monarchs of Europe, can lend credence to the likelihood of such plans. According to the note, in addition to the liquidation of the representative bodies and the restoration of the new dynasty, there also was an idea about the partition of France, which was rejected later ${ }^{12}$. The fear was omnipresent and made allusions to the partition of Rzeczpospolita. It was not a coincidence that in the course of the hundred days of Napoleon one of the newspaper

${ }_{10}$ Nechkina M. V. Griboedov i dekabristy. Moscow, 1951. P. 208.

11 Potapova N.D. Tribuny syrykh kazematov. Politika i diskursivnye strategii v dele dekabristov. St. Petersburg, 2017. P. 20-21, 26.

12 Pasquer É.-D. Mémoires du chancelier Pasquier: histoire de mon temps. Paris, 1893. T. 4. P. 251. 
items put a speech with the following words: "France wants to remain France instead of being partitioned and disintegrated like Poland"13.

The history of the Congress of Vienna and the decisions regarding the destiny of Poland are widely represented in historiography by a number of works by both Russian and foreign historians, among which S. M. Solov'ev ${ }^{14}$, N. K. Shil'der ${ }^{15}$, V. Timoshchuk ${ }^{16}$, S. Vebster $^{17}$, L. A. Zak ${ }^{18}$, M. A. Dodolev ${ }^{19}$ and others should be mentioned. At the same time, the history of the French press has also been thoroughly explored and scrutinized from all points of view ${ }^{20}$. However, until recently the question of the impact of the Polish-Lithuanian themes on the French liberal discourse of the era of Biedermeire has not been raised.

The events of the Congress of Vienna were crucial for the French press in the first years after the defeat of Napoleon Bonaparte. Both rumors and official statements were used. Different opinions about Poland were voiced, but judging by the tone of the publications the majority spoke out in favor of granting some form of statehood to the Poles. Accordingly, the information that Russia, Prussia and Austria had reached a compromise with regard to the Polish question, obtained from reliable sources, was received with universal approval: it was emphasized that it was in harmony with the national interests of Poland $^{21}$. The news about the final decision on Poland gave rise to universal enthusiasm despite the fact that some issues (for example, the demarcation) had not been settled out yet $^{22}$.

All the while, despite the positive sentiments, the royalist press expressed certain disapproval with regard to the legitimacy of the new rule. The Congress of Vienna and the related events produced a negative reaction on the part of both the Bonapartistes and the royalists. The latter challenged the right of the Great Powers to redraw the map of Europe. The incorporation of Poland into Russia by means of dual monarchy was taken negatively as Alexander I neither had any hereditary rights to the Polish crown nor was he at least elected as many kings of Rzeczpospolita were ${ }^{23}$.

Comments on these publications can be found in the memoirs of N.I. Grech, who used to draw information from European newspapers having no access to other sources: "Europe interpreted this demand [to restore Poland as an independent state and to grant it a constitution] as an ambitious plan of Russia to expand its territory and reinforce its strength" 24 . The British public also denounced the policy of the Congress of Vienna. The idea of the partition of Europe was met with outright hostility. Alexander I was reminded

13 Journal des débats politiques et littéraires. 1815/06/02.

14 Solovev S. M. Venskii congress // Russkii vestnik. 1865. Vol. 55, no. 2. P. 375-438.

15 Shil'der N. K. Imperator Aleksandr Pervyi. Ego zhizn' i tsarstvovanie. Vol.3. St. Petersburg, 1897. P 269-320.

16 Timoshchuk V. Aleksandr I i pol'skii vopros na Venskom kongresse. Po dokumentam agentov Venskoi tainoi politsii // Russkaia starina. 1914. Vol.157, no. 1. P. 135-145.

17 Webster C. The congress of Vienna (1814-1815). London, 1920.

18 Zak L.A. Monarkhi protiv narodov. Diplomaticheskaia bor'ba na razvalinakh napoleonovskoi imperii. Moscow, 1966.

19 Dodolev M. A. Venskii kongress v istoriografii XIX-XX vekov. Moscow, 2000.

${ }^{20}$ Les voix du lecteur dans la presse française au XIXe siècle. Limoges, 2018.

${ }^{21}$ Journal des débats politiques et littéraires. 1815/03/01.

22 Ibid. 1815/04/26.

${ }^{23}$ Ibid. 1815/05/14.

${ }^{24}$ Grech N. I. Zapiski o moei zhizni. Moscow, 1990. P. 214. 
of his words pronounced in Paris after the defeat of Napoleon: "The ruler has to follow the impulses of the human nature - otherwise he will run into an impending disaster"25.

However, soon the flow of the anti-Russian accusing publications stopped. They gave way to the news about the establishment of the borders between the newly formed Polish Kingdom and other European powers ${ }^{26}$, about the manifests of Alexander I to the Polish people ${ }^{27}$, and also about the arrival of the military and civic delegations to swear allegiance to the Russian Emperor as to their new king ${ }^{28}$. It is noteworthy that the news about the oath was published mostly by the royalist periodicals, such as the Journal des Débats. The liberal ones, for example, Le Constitutionnel, - on the contrary, focused on the issues of demarcation and the operations of the Russian troops.

We believe the tone of the publications to have changed mostly due to the Polish military and civic elites swearing allegiance to the Russian Emperor. This was evidence of the positive attitudes towards the results of the Congress of Vienna in the Polish society. In fact, it can be stated that the status of Poland improved in comparison with the previous period. Instead of being the Duchy of Poland, it became a kingdom, related to Russia not by the subordinate acts but by the personal monarchical union.

In November 1815, Alexander I planned to pay his first official visit to Poland and to enter Warsaw with triumph, as one of his "new" capitals. The prospective visit mostly aimed at the formation of the new government and the promulgation of the constitution of the Kingdom of Poland. It is interesting to mention that this important document was drawn up not by some state commission called for this occasion, but by private persons, in particular, Alexander Linovskii and Ludwik Plator $^{29}$, on the basis of the principles articulated by the Emperor in May 1815 with the assistance of Count Adam Chartoryisky, who was aptly characterized by the historian Ch. Morley as an unofficial "chief of staff for Polish affairs" ${ }^{30}$. We will also touch upon the role of Chartoryisky in shaping the polonopfilic views of Alexander I, which can hardly be overestimated: in fact, the Russian Emperor discussed Polish-Lithuanian issues throughout his relationship with Chartoryisky ${ }^{31}$.

The French public was impatiently looking forward to the historic visit and the adoption of the new constitution as a responsibility of Alexander $\mathrm{I}^{32}$. Throughout the autumn of 1815 , the editors of the main newspapers were making attempts to predict its content and origins. To start with, the journalists referred to the Peace Treaty of Paris of $1814^{33}$, having published all the items related to Poland. It was this treaty that established the new borders of Europe and contained the supplementary agreement between France and the Russian Empire about the fate of the Duchy of Warsaw ${ }^{34}$. After that, they focused on the Treaty of the Holy Alliance ${ }^{35}$, which prolonged the new Vienna system of international

25 Journal des débats politiques et littéraires. 1815/03/27.

${ }^{26}$ Le Constitutionnel: journal du commerce, politique et littéraire. 1815/11/14; 1815/11/16.

27 Journal des débats politiques et littéraires. 1815/05/30.

28 Ibid. 1815/08/13; 1815/09/01.

29 Askenazy Sh. Tsarstvo Pol'skoe (1815-1830). Moscow, 1915. P. 28.

30 Morley Ch. Czartoryski as a Polish Statesman // Slavic Review. 1971. Vol.30, no. 3. P. 606-614, 610.

31 Morley Ch. Alexander I and Czartoryski: The Polish Question from 1801 to 1813 // The Slavonic and East European Review. 1947. Vol.25, no. 65. P. 405-426.

${ }^{32}$ Le Constitutionnel: journal du commerce, politique et littéraire. 1815/11/16.

33 Ibid. 1815/11/27.

34 Article additionnel au Traite avec la Russe // Recueil des traités et conventions entre la France et les puissances alliées en 1814 et 1815. Paris, 1815. P.22-23.

${ }^{35}$ Le Constitutionnel: journal du commerce, politique et littéraire. 1815/12/03. 
relations and a place of Poland in it by providing the guarantees of the adopted agreements, namely Russia, Austria and Prussia ${ }^{36}$. Having outlined the framework of the future universal political system, the newspapers focused on the above-mentioned principles of the new Polish constitution. All the provisions were published in succession both in the royalist and Bonapartist editions, while they were waiting for the news from Warsaw, and even after that ${ }^{37}$.

It should be noted that there were other drafts of the constitution, containing either criticisms of the previous constitution of the Duchy of Warsaw based on the Napoleonic Code, or general speculations on this subject ${ }^{38}$. Wide dissimilation of various texts of "constitutions" and "false constitutions" was indicative of the growing public interest in this matter ${ }^{39}$. This phenomenon in the Russian society can be attributed to the involvement of the French media in this topic.

It is significant that the constitution of the "new" state was not imposed by the state monarchic machine. On the contrary, Alexander I openly trusted the representatives of the Polish establishment to draft the constitution. Such a strategy indicates that Alexander I acted intentionally, posing as a liberator rather than a conqueror in front of Europe and wishing to demonstrate his respect for the will of the Polish people. Thus, the Emperor of Russia followed the principles of the "external" or "false" liberalism mentioned by S. B. Okun' ${ }^{30}$. At the same time, beyond the public sphere Alexander I adhered to the tough policy of autocracy, not of liberal monarchy. This became especially apparent in the course of the Congress of Vienna, where the Emperor with the help of A. Chartoryisky in response to a memorandum of Lord Robert Stewart Castlereagh made the following statement: “...All the decisions his Majesty the Russian Emperor might make with regard to the establishment of the new order in the Polish provinces belong to the realm of home policy, the sphere where his Imperial Majesty is not accountable to anyone" 41 .

It is worth mentioning that this policy of the Emperor was successful to a certain extent. His visit to Warsaw was widely covered by the French press which gave a detailed account of his stay, including a ceremonial dinner attended by Russian and Polish military commanders of high rank - the fact which was supposed to emphasize the reconciliation of the previously hostile sides. What is more, special attention was given to a speech of Alexander I delivered in front of the Polish deputation. In particular, he expressed his regret for all the hardships suffered by the Polish land during the Napoleonic Wars, and assured the audience that he devoted all his time to the prosperity of his country and the wellbeing of its citizens, including the Poles ${ }^{42}$. The emperor also issued a decree about the new monetary system of the Kingdom, according to which the obverse of all new coins

36 Traktat bratskogo khristianskogo soiuza // Polnoe sobranie zakonov Rossiiskoi imperii. St. Petersburg, 1830. Vol.33, no. 25943. P. 279-280.

${ }^{37}$ Le Constitutionnel: journal du commerce, politique et littéraire. 1816/01/04; 1816/01/11; Journal des débats politiques et littéraires. 1816/01/15; Le Constitutionnel: journal du commerce, politique et littéraire. 1816/01/16.

38 Shchegolev S. I. Aleksandr I i pol'skaia konstitutsiia 1815 g. // Trudy kafedry istorii Novogo i Noveishego vremeni. St. Petersburg, 2014. No. 12. P. 82.

${ }^{39}$ Liubeznikov O.A. Russkie teksty pol'skoi konstitutsii 1815 goda: perevody i mesto $\mathrm{v}$ istoriografii // Mavrodinskie chteniia - 2018. Materialy Vserossiiskoi nauchnoi konferentsii, posviashchennoi 110-letiiu so dnia rozhdeniia professora Vladimira Vasilevicha Mavrodina. St. Petersburg, 2018. P. 256-257.

${ }^{40}$ Okun' S. B. Istoriia Rossii. 1796-1825. Leningrad, 1947. P. 121.

${ }^{41}$ Cit. by: Askenazy Sh. Tsarstvo Pol'skoe (1815-1830). P. 22.

${ }^{42}$ Le Constitutionnel: journal du commerce, politique et littéraire. 1815/12/12. 
had to bear an inscription: "Alexander I, the Emperor and Autocrat of all Russia, the King of Poland etc", and the reverse - the emblem of Poland ${ }^{43}$.

The signing and promulgation of the Polish constitution gave rise to great public enthusiasm. The news had reached Paris by mid-January 1816. French newspapers gave an account of the events in Warsaw, and discussed the liberal nature of the constitution and its conforming to the aspirations of the Polish nation. The adoption of the new constitution was claimed to have been a monument to Alexander I erected in his lifetime. It was also argued that it was Alexander I who helped the Polish people reclaim one of the most important elements of their national existence ("son existence nationale") lost due to the specific geographical location of the country ${ }^{44}$ at the intersection of the interests of Russia, Austria and Prussia. The information that the Polish army on the way back from France had come right up to Warsaw and was only waiting for the orders of the Grand Prince Constantine also played an important role ${ }^{45}$.

The enthusiasm of the French press was quite natural as Alexander I was perceived as an advocate of the model of liberal monarchy popular with the French publicists of that period. The situation largely repeated the case of the French Charter of 1814, when the constitution was granted by a monarch who gave it to the people of his own free will, thus having made a social compact with them. B. Constant personally supported the initiatives of Alexander I in Poland. In particular, he observed: "...Emperor Alexander has more freedom with regard to the system he grants to Poland, since a land lying in ruins represents a new ground for an architect; he consoles it introducing the constitution and restoring many political rights" 46 . In parenthesis, we mention that it was in 1816 that B. Constant reached the peak of his career as a writer and publicist whose works were the focus of public attention ${ }^{47}$.

Even Great Britain, whose public had previously demonstrated hostility against Russia and the Congress of Vienna, did not miss out on the events. For example, the Courier published an article in response to the rumors about a new war in Europe, spread by radical French newspapers. It claimed that Russia's intention was only to bring peace to the European continent in order to restore the state after a hard and lingering war with Napoleon ${ }^{48}$.

Thus, the French press articulated the discourse of a liberator-tsar: Alexander I did not defeat Napoleon to become a new Napoleon himself. His only concern was the well-being of his new subjects: the Poles were coming home from a long war to receive the desired freedom represented by their own constitution thanks to the Russian Emperor. It is noteworthy that the impression was directly contrary to the one concerning the partition of Rzeczpospolita. In fact, both under Catherine II and Alexander I Russia pushed away the western border in order to annex new lands. However, according to French publicists, the events of the 1795 were interpreted as usurpation and servitude, while those of 1815 - as long-awaited freedom.

${ }^{43}$ Ibid. 1816/01/10.

44 Journal des débats politiques et littéraires. 1816/01/16; Le Constitutionnel: journal du commerce, politique et littéraire. 1816/01/16.

${ }^{45}$ Le Constitutionnel: journal du commerce, politique et littéraire. 1816/02/10.

${ }^{46}$ Mercure de France. 1817/01/18 (Constant B. Tableau politique de l'Europe. P. 106).

47 Valette R. M. Benjamin Constant, Dramatic Theorist // The French Review. 1964. Vol.37. P.426431.

48 The Courier. 1816/07/10; Journal des débats politiques et littéraires. 1816/07/13. 
Being at the height of his fame, Alexander I performed a deed which largely contributed to his already established positive image. It involved the commemoration of Jozef Poniatowski. As a true patriot of Poland, the commander-in-chief of the Polish army of Napoleon and the only foreigner awarded a title of the marshal of France, he had the status of a national hero ${ }^{49}$. After the conclusion of the Peace Treaty of Paris in 1814, Alexander I ordered to bring the body of J. Poniatowski back to his homeland to pay last respects. This highly symbolical mission was assigned to Grand Prince Constantine Pavlovich; later on the Emperor even had a monument set up in the honor of Poniatowski. The Polish society met this gesture of the Russian Emperor with great enthusiasm and demanded this from the people of other European countries.

In June 1815, the Journal des Débats published an anonymous, rather impartial article about J. Poniatowski ${ }^{50}$, which brought about a stream of criticism. Next year the editors published a letter, presumably, written by a person from the Polish political elite. References to various private matters and events taking place in Poland are indicative of this. The author deplores the French press for insulting the memory of the Polish hero and emphasizes the role of Alexander I as his new ruler in the transportation of the body of the marshal to his fatherland: "With gratitude and sorrow did Poland receive this bitter-sweet gift of its new Emperor as the first sign of his virtues $\langle\ldots\rangle$. An extremely moving ceremony in Warsaw contributed to the deep impression left by this gift" 51 .

Thus, Alexander I due to the efforts of the French press was featured not only as a liberator-tsar, but as a ruler guided by the national perceptions of national interests. It is also worthy of note that such articles did not generate debates, and such a representation became indisputable and generally accepted. This new image of the Russian Emperor evoked the sympathies only of the European public, in the eyes of which Alexander I wanted to appear as an "equal", not a barbarian from the east. Praising its new idol, the French press proved to be so persuasive that even the representatives of the Russian and Polish public were made to believe in the polonophilia of the Emperor.

A well-known work by N.I. Turgenev accentuates the decisive role of the discourse developed by the French press: "Credit must go to Alexander I for everything what has been done for Poland... It was the Emperor who created the Kingdom of Poland and gave it the constitution" 52 . As we can see, the author of the memoirs almost word for word repeats the main ideas circulating in the analyzed publications of that time.

The scale of the Emperor's polonofilia, featured by the public consciousness, can hardly be overestimated. According to the Polish researcher A. Hental: "historians are not sure that Alexander really wanted to unite Lithuania and Volhynia with the Kingdom of Poland, but many contemporaries believed that Alexander had made such promises and that he would have kept them if he had not died suddenly in December 1825"53. The discourse created by the French press unintentionally touched upon a covert domestic Russian conflict. Thus, W.H.Zawadzki argued: "In his relations with Poland, Alexander I

49 Capelle B., Demory J.-C. Maréchaux d'Empire. Paris, 2008. P. 106.

50 Journal des débats politiques et littéraires. 1815/06/11.

51 Ibid. 1816/08/16.

52 Turgenev N. I. Rossiia i russkie. Moscow, 2001. P. 40.

${ }^{53}$ Hetnal A.A. The Polish Right and The Question of National Independence in Russian Poland (1815-31). The Case of General Augustyn Słubicki // The Polish Review. 1986. Vol.31, no. 1. P. 20. 
therefore appeared both as a conqueror and a magnanimous liberator. Most of his ministers and advisers remained hostile to his Polish plans" ${ }^{\text {" }}$.

A certain marker of the developing opposing discourse was the treatment of this topic by the Decembrists. "Hostility to Poland had been an important factor in the origin of Russian secret societies" 55 , - noted the American historian F. Walker. W.L. Blackwell in his article providing an insight into the attitude of the Decembrists to the Polish question emphasized that "Alexander I's pro-Polish policy in the half decade following the Congress of Vienna, when the early societies were active, provokes vigorous and hostile reactions in Russia and it is to be expected that the young liberal nationalists of the early Decembrist groups also would develop animosities toward the Poles" 56 . Moreover, A. Mazour stated that the internal struggle, which resulted in the events of the September 1817, was taking place against the background of the news about the constitution granted to Poland ${ }^{57}$.

In the Soviet historiography, the views on this issue were different. The anti-Polish sentiments of the "Order of the Russian Knights" did not raise doubts but were associated exclusively with their belonging to the hereditary aristocracy" 58 . The key episode - the famous Moscow Conspiracy of 1817 was also interpreted in a different way. According to M. V.Nechkina, Alexander I planned to affiliate western provinces to Poland: "The idea of taking away some vast aboriginal Russian territories together with the insulting legislation and the impending people's revolt, which could, from the point of view of the Decembrists, ruin everything caused their indignation and demanded immediate actions" 59 . Hence, wounded patriotic feelings were believed to have been the main trigger of the regicide plan.

Soviet historians recoded the jealousy of the reforms in Poland into hurt patriotic feelings. The focus on the former (polonophobia) would have ruined the image of the "heralds of freedom", whereas putting the accent on the struggle for the inalienability of the lands of Ukraine and Belarus helped to level the obvious dissonance. That is why this view has taken root in the Russian historiography. It appears that the interpretation of a source should not turn into a fantasy on a "given topic": the causes of the Moscow Conspiracy are to be sought in the peasant question ${ }^{60}$, and the Polish issue in the Decembrist ideology should be explored separately. All the more so, it would be wrong to speak about a consolidated movement and a unified ideology ${ }^{61}$.

The Russian Emperor spared no efforts to preserve the image of a liberal monarch and publicly declared about his intention to enter Poland not like a winner or invader, but like a father to his new subjects ready to support them in all possible ways ${ }^{62}$. This image

${ }^{54}$ Zawadzki W.H. Russia and the Re-Opening of the Polish Question, 1801-1814 // The International History Review. 1985. Vol. 7, no. 1. P. 41.

55 Walker F. A. Poland in the Decembrists' Strategy of Revolution // The Polish Review. 1970. Vol.15, no. 2. P. 44 .

56 Blackwell W. L. Russian Decembrist views of Poland // Ibid. Vol.3. no. 4 (Autumn) 1958. P.31-32.

57 Mazour A. G. First Russian revolution 1825. The Decembrist movement. Its origins, development and significance. Stanford, California, 1937. P.71.

58 Ol'shanskii P. Dekabristy i pol'skoe natsional'no-osvoboditel'noe dvizhenie. Moscow, 1959. P. 38.

59 Nechkina M. V. Dvizhenie dekabristov. Vol. 1. Moscow, 1955. P. 176.

${ }^{60}$ Belousov M. S. Moscow Conspiracy of the Decembrists // Vestnik of Saint Petersburg University. History. 2018. Vol.63, iss. 1. P.29-40.

${ }^{61}$ Belousov M.S. Disputes about Speaking from their Cells // Vestnik of Saint Petersburg University. History. 2019. Vol. 64, iss. 3. P. 1160-1173.

62 Journal des débats politiques et littéraires. 1816/09/24. 
attracted the French press, both royalist and liberal, which contributed to the created impression and facilitated the spread of the discourse all over Europe. The journalists gave a detailed complimentary account of the visit of Alexander I to Poland in October 1816, emphasizing such actions as his personal reception of military and civic deputations, the wearing of Polish uniform, the reconstruction of Yablonovsky Palace into a new city hall, and the pronounced observance of the constitution articles ${ }^{63}$.

The Russian Emperor was praised for his efforts in the realm of education. This sphere figured prominently in the value system of the liberal public both in France and all over Europe. It was indicated that under Alexander I numerous new schools and seminaries, which had achieved quite a high level of tuition in a short space of time, were opened $^{64}$. The application of various teaching techniques and the attempts to introduce new foreign methods in this field were also mentioned. For example, specifically with this goal in mind, a young teacher, trained in England, was assigned to work in Warsaw ${ }^{65}$. Such feedback shaped the image of the Russian Emperor as of a truly enlightened monarch.

It can be stated that throughout the subsequent period between 1816 and 1818, the French public took less interest in the Polish agenda. Absolute confidence in the liberal course pursued by the Emperor and, correspondingly, in the well-being of the Polish nation can account for this. The publicists focused their attention on the domestic issues of France: the legitimacy of various actions of the Bourbon dynasty, restrictions on the freedom of speech, the formation of the budget, etc.

A new surge of interest was related to the famous Warsaw Speech of Alexander I, delivered at the opening of the Polish Sejm on March 15, 1818. The reaction to it demonstrates a change of attitude towards the Emperor and his "liberal" policy. Having published the shorthand record of the speech ${ }^{66}$, The French press conveyed the key ideas of Alexander I not only to Europe, but to Russia as well as the European press was practically the only source of information for the Russian elite. Thus, the Emperor in his traditional manner attempted to know the response of the public to his ideas about the extension of the constitutional principles to Russia. The obscure wording provided an opportunity for a political maneuver and allowed the Emperor to learn the opinion of the public on that matter ${ }^{67}$.

This attempt to monitor the public opinion proved to be successful. Each group saw in it what they expected from the supreme authority, and what they feared most of all. By mid-summer 1818, the representatives of all the segments of the Russian nobility were deeply impressed, albeit in an ambiguous way, and gave their assessment of the Warsaw speech. Russian political elite of high rank were amazed at the idea of the creation of Russia' own constitution ${ }^{68}$. For example, A. A. Zakrevsky in his letter to P. D. Kiselev of March 31, 1818 wrote: "the speech of the Emperor delivered at the Sejm was excellent but its

${ }^{63}$ Le Constitutionnel: journal du commerce, politique et littéraire. 1816/10/22; 1816/12/01.

64 Journal des débats politiques et littéraires. 1817/10/13.

65 Ibid. 1817/09/23.

${ }^{66}$ Ibid. 1818/04/15.

67 Chernov K. S. "Gosudarstvennaia Ustavnaia Gramota Rossiiskoi Imperii” (k voprosu o rossiiskom konstitutsionalizme): dis. ... kand. ist. nauk. Moscow, 2007. P. 62.

${ }^{68}$ Mironenko S. V. Samoderzhavie i reformy. Politicheskaia bor'ba v Rossii v nachale XIX v. Moscow, 1989. P. 58. 
consequences can be fatal for Russia; this is clearly seen from its content. I did not expect him to have revealed his opinion on this matter so soon" 69.

In this context, historians tend to refer to the episode of N.M. Karamzin lecturing P. A. Viazemsky. The former in his letters tried to persuade his "liberally-oriented" friend that in contrast to Poland, the constitutional model was not suitable for Russia ${ }^{70}$. In 1819 , N.M. Karamzin in the evening that followed the conversation with Alexander I "in a few hours prepared what was to become one of the most famous Russian tracts on the Polish Question"71 — "The view of a Russian citizen"72, in which the historian made skeptical observations on the polonofhilic initiatives of the Emperor. According to J. Flynn, it was the historian's reaction not only to the Warsaw Speech but rather to the general situation with Poland that frightened him ${ }^{73}$.

Undoubtedly, the speech of the Emperor targeted the Russian public in the first place and after it - the European. Under the circumstances, the French press became a kind of a mouthpiece for the ideas of Alexander I. The full text of the speech was published in French newspapers, with the public response to it being much more reserved than in the case with the constitution. At the time, newspapers in several issues were trying to trace the origins of the Polish constitution of 1815, however, in 1818, the situation changed completely. For example, when the news about the first draft of the State Charter of the Russian Empire reached Paris, Le Constitutionnel published only a small item about the prospective introduction of the constitution in Russia, having outlined its main principles $^{74}$.

This reserved reaction can be put down to the fact that the French liberals did not expect the constitutional rule to be introduced in Russia so soon, as distinct from Poland where the level of the public relations accounted for this. According to them, the Russian society was not ready for that ${ }^{75}$. This cautious rhetoric might have been caused by the fact that at that time the so-called "honeymoon" of Alexander I and the French press was nearing its end. The falsity of his decisions, in general, and the sham nature of his liberal policy, in particular, gradually revealed themselves, which resulted in the change of attitude to both the Emperor and Russia.

The grounds for such changes also occurred before, but the press, especially the royalist periodicals, did not make much of them. Thus, at the end of December 1816 the press published the news about the rules of compulsory military service in the Kingdom of Poland and the establishment of gendarmerie to maintain public security ("la sûreté publique" ${ }^{76}$; after a while a new system of conferring the titles of nobility and the titles of a prince and a count also met with criticism ${ }^{77}$. The enthusiasm of the French press inspired

69 Davydov M. V. Oppozitsiia ego velichestva. Moscow, 1994. P. 93.

70 Shul'gin V.N. Russkii svobodnyi konservatizm pervoi poloviny XIX veka. St. Petersburg, 2009. P. 111.

71 Black J.L. Nicholas Karamzin's “Opinion” on Poland: 1819 // The International History Review. 1981. Vol. 3, no. 1. P.1.

72 Karamzin N.M. Mnenie russkogo grazhdanina // Neizdannye sochineniia i perepiska Nikolaia Mikhailovicha Karamzina. Ch. I. St. Petersburg, 1862. P. 186.

73 Flynn J. T. Uvarov and the "Western Provinces": A Study of Russia’s Polish Problem // The Slavonic and East European Review. 1986. Vol. 64, no. 2. P.212-236.

74 Le Constitutionnel: journal du commerce, politique et littéraire. 1819/11/21.

75 Parsamov V.S. Dekabristy i frantsuzskii liberalism. Moscow, 2001. P. 72.

76 Journal des débats politiques et littéraires. 1816/12/31.

77 Ibid. 1817/08/09. 
by the events of 1815-1816 was gradually withering away. At the same time, a definite discord was present in the coverage of the Polish events - depending on the pro-government or anti-government views of the periodicals.

Such newspapers as Le Journal de Paris, L'Etoile, La Gazette, Le Moniteur, Le Drapeau blanc, Le Pilote supported the government. Among these, Le Journal des Débats, published in large editions, was the most influential in comparison with other pro-government newspapers. Le Constitutionnel, in turn, became a mouthpiece for the opposition, backed by La Quotidienne, Le Courrier francais, Le Journal de Commerce, L'Aristarque ${ }^{78}$. Stendhal noted the numerical superiority of the opposition-minded press, having written about the popularity of Le Constitutionnel with the country people, in contrast to the inhabitants of the palaces who preferred Le Journal des Débats ${ }^{79}$.

A letter of Polish origin published in a liberal journal La Minerve française $e^{80}$ served as a signal of this discord. Under the guise of nominal praises to the Emperor, the letter expressed concerns about Russia being not a guarantor of the freedom of Poland, but rather its oppressor. Various reforms of the army with the purpose of strengthening the discipline were claimed to be articulated in the terms of the relationship between a parent state and a colony. In 1819, the remarks about Alexander I keeping his word unlike other European monarchs and pursuing a liberal policy were perceived as a mere mockery. The hopes of the French liberals, which date back to 1814-1815, were destroyed in 1819 when the fictitiousness of the Polish constitution became obvious ${ }^{81}$.

The liberal public of France mostly resented the restriction of the freedom of speech and press in Poland, which they considered to be one of the most important elements of the human rights. The news about the suspension of the $16^{\text {th }}$ clause of the Polish constitution, which was supposed to guarantee these rights, and the introduction of the strict preliminary press censorship by the state gave rise to a predictable outburst of indignation. Thus, La Minerve française explicitly quoted the above mentioned clause pointing out that Alexander I had personally put his name beneath it some time ago. His actions encouraged the editors to claim that the coalition against the freedom of speech had started to develop in Europe ${ }^{82}$. The press would publish letters from Poland exposing a growing tension within the country. For example, one story provided information about a Polish student who was forced to drop out of law school and to leave his city due to the frequent arrests of young people on the ground of their political views and the opposition to the imperial administration ${ }^{83}$.

The royalist mass media, on the contrary, continued to cover the Polish affairs in the same vein. They happily commented on the news that the former Polish-Lithuanian lands, which were part of Russia, could have been affiliated with the Kingdom of Poland. Alexander I was praised as a peacemaker of Europe ("le fondateur de la paix de l'Europe") who was eager to restore the rights of all the peoples of Europe under the motto: "suum cuique" ${ }^{\prime 2}$. Later, in 1820, Le Journal des Débats published a full version of the speech de-

78 Solodovnikova T. Yu. Sharl' Bodler i stanovlenie literaturno-khudozhestvennoi zhurnalistiki Frantsii: Pervaia polovina - seredina XIX v.: diss. ... kand. filol. nauk. Krasnodar, 2000. P. 24-26.

79 Ledre Ch. Histoire de la Presse. Paris, 1958. P. 191.

${ }^{80}$ La Minerve française. Paris, 1819. T. 6. P.336-343.

81 Parsamov V.S. Dekabristy i frantsuzskii liberalism. P. 72-73.

${ }^{82}$ La Minerve française. Paris, 1819. T.7. P. 523-525.

${ }^{83}$ Le Constitutionnel: journal du commerce, politique et littéraire. 1821/08/12.

${ }^{84}$ Journal des débats politiques et littéraires. 1819/02/05. 
livered by the president of the Polish Senate S. K. Pototski at the opening of the Sejm and addressed to Alexander I. In the speech, he indicated that the Russian Emperor recovered tranquility in Europe and played a key role in the European affairs not due to his strong presence on the continent, but due to his power over human hearts. At the same time, he argued that the constitution of Poland, which had risen from ashes, was ample evidence of Alexander' sincere love for the humanity. Moreover, it was due to the policy of Alexander I that the Polish farmers could cultivate the land and did not know the "horrors of oppression" 85 .

The changes in the pro-government press began to show only in the early $1820 \mathrm{~s}$. In general, it can be stated that in the above-mentioned period Alexander I lost interest in the Polish affairs: before that he had systematically visited the country and used to keep up with the main events ${ }^{86}$. In the 1820s, the era of southern revolutions began: the events in Italy and Spain led to a series of congresses of the Holy Alliance, with the French press focusing its keen interest on them. The aggravation of the situation in Europe, including the conflict over the Eastern question, changed the representation of the Polish question.

Le Journal des Débats, having published a shorthand record from the French Chamber of deputies meeting on the international balance of forces, quoted L. Bignon who insisted that the European Powers under the pretext of maintaining order introduced censorship and oppressive regimes, also invading the lands of their neighbors. He referred to the partition of Poland and the "usurpation" of the Crimea to confirm this statement, having added in the end that France would always be ready to put its Tartuffes and Basilios against foreign Mohammads ${ }^{87}$ and Tamerlanes ${ }^{88}$. Thus, the former foreign minister of France compared Russia to these great conquerors of the past, using an explicit negative connotation. The British press also came up with similar rhetoric. The above-mentioned royalist French source reprinted the analytic item from The Morning Chronicle about the revolt in Greece. It claimed that Great Britain had to interfere in the situation otherwise Russia would subjugate the Greeks in the same way as it happened to the Poles ${ }^{89}$.

Therefore, the French press returned to the discourse about the barbarian neighbor from the east. Thus, the image of a liberator-tsar transformed into that of a brutal despot and usurper who would take advantage of any possibility to subjugate European lands. One more newspaper item which argued that the Congress of Vienna had made a huge mistake having failed to demand the revival of Poland despite its efforts to restore the rights of the peoples and the balance of forces in Europe, confirms a complete reversal in the rhetoric of the pro-government media ${ }^{90}$. Russia took part in this international forum as one of the winners. Russian weaponry brought the French the long-awaited freedom from Bonaparte. However, eight years later these negotiations would be featured as an attempt of negotiations between free Europe and despotic Russia.

The return of the nominally homogeneous rhetoric of the French press applied to Alexander I and his policy towards Poland marked the final transition of a liberal image of the Russian Emperor into a symbol of usurpation and lust for power. In particular, it was

${ }^{85}$ Ibid. $1820 / 10 / 10$.

86 Thackeray F. W. N.N. Novosil'tsov, The Polish Years // The Polish Review. 1983. Vol.28, no. 1. P. 35-36.

87 The minister refers to the Great Arab conquests.

${ }^{88}$ Journal des débats politiques et littéraires. 1821/04/11.

89 Ibid. 1821/11/02.

90 Ibid. 1823/01/03. 
due to the efforts of the French press, supported by the liberal public, that the word "Russians" became a common noun, striking terror into the hearts of Europeans. The major mouthpiece of these ideas was Le Constitutionnel.

The Holy Alliance was criticized for its ambition for absolute dominance, the oppression of East European civilizations and conniving at Russia, which allegedly took advantage of it $^{91}$. All the declarations of the peaceful disposition of the Russian Emperor were dismissed, and Poland was featured as an embodied disgrace for Europe - as all the countries of the continent had failed to protect its interests ${ }^{92}$. There were references to quotes from Napoleon Bonaparte, who stated that the Europeans would see his intention to restore Poland as a buffer to keep away from the menacing Russian Empire which aimed at invading Europe. The Russians were portrayed as barbarians striving to conquer their neighbors, being unable to free their own lands ${ }^{93}$. It can be stated that all the main concepts of the perceptions of the Polish affairs in the first quarter of the $19^{\text {th }}$ century were revised: Napoleon was reported to have been a protector of the European values in the context of the Russian threat; the puppet Duchy of Warsaw was seen as an outpost of civilization, and the Russians from liberators turned into bloodthirsty slaves of the brutal despot.

It is noteworthy that some part of the Russian public accepted this discourse; for example, P. A. Viazemsky, who became an advocate of the liberal position of the French with regard to Poland. After the publication about the abrogation of the $16^{\text {th }}$ clause of the constitution of the Kingdom of Poland, he expressed his indignation at the actions of St. Petersburg towards the Poles in the following words: "I am so horribly angry, as if the Polish blood were running in my veins, as if I did not live in the accompaniment of lashings and irons and was not brought up on a naughty step. Presumably, I was supposed to get accustomed to everything! But no, this foreign blood is bubbling inside me!" 94 Similar views can be found in the texts of N.I. Turgenev: "This decision was harmful for the Polish provinces. The arrests started, many Poles were prosecuted and sentenced with little or no proof" 95 . Here word-for-word quotes from the French press can be found.

The intention to liberate Poland from the Russian oppression is visible in the plans of the Decembrists. P. I. Pestel' wrote in "Russkaia Pravda" (the Russian Truth) that "in the case of Poland the right of Nationality in all fairness should prevail over the right of Convenience" ${ }^{96}$. In this statement, he obviously sided with the liberals who considered Poland to be an independent self-reliant state. At the same time, according to V.S. Parsamov, the Decembrist viewed Poland as a tool to export revolutions to neighboring Austria and Prussia through the establishment of a puppet state on its territory. Under the protection of the new Russia, it would have helped to turn "independent" Poland into a buffer between Russia and Western Europe ${ }^{97}$. However, here P. I. Pestel', albeit in the wrong way round, again repeats the ideas of the French, who from the early $18^{\text {th }}$ century perceived

${ }^{91}$ Le Constitutionnel: journal du commerce, politique et littéraire. 1821/02/13; 1821/03/23.

92 Ibid. $1821 / 06 / 25$.

93 Ibid. 1822/07/19.

94 Ostaf'evskii arkhiv kniazei Viazemskikh. Vol. 1. St. Petersburg, 1899. P. 347.

95 Turgenev N.I. Rossiia i russkie. P. 51.

96 "Russkaia Pravda" P. I. Pestelia i sochineniia, ei predshestvuiushchie // Dokumenty po istorii vosstaniia dekabristov. Vol. 7. Moscow, 1958. P. 123.

97 Parsamov V.S. Dekabristy i frantsuzskii liberalism. P. 80-84. 
Poland as a shield from Russian "barbarians" and a base for the propagation of the liberal values in the east.

It should be kept in mind that even in the secret societies of the Decembrists such a viewpoint was considered to be quite marginal. In the spring of 1824, P. I. Pestel' arrived in St. Petersburg and had several meetings with the leaders of the Northern Society. All in all, the meetings proved to be unsuccessful and resulted in the confrontation between P. I. Pestel' and S. P. Trubetskoy. In "Zapiski" (the Notes), the latter outlined the main controversial issues, which evoked a negative reaction in St. Petersburg, with the Polish question being among them. Pestel's ideas from "Russkaia Pravda" were greeted with hostility by Trubetskoy. At the inquest, he would say: "I have heard all this rubbish and informed our members that Pestel" was talking gibberish" ". The view of the Northern Society on this problem was different: "It is impossible to concede to Poland the territories our fathers had shed their blood for. Poland should remain the property of Russia but for the sake of justice the Poles as well as other peoples, conquered by the Russians, should enjoy the same rights" 99 .

The position of Trubetskoy does not agree with the one of P.I. Pestel' or with the stand of Russian conservatives. He could not follow the polonophilic discourse of the liberals and acknowledged the necessity of the constitutional policy in the national borderlands. Similar debates would occur in the Russian intellectual circles throughout the $19^{\text {th }}$ century. In a due course nationalist publicists would nickname Alexander I "Arakcheev's humanist" for his contribution to the development of the Polish question ${ }^{100}$. However, the analysis provided by the paper undoubtedly confirms that only the "reference to the European press can fill the gaps of the political imagination and subjectivity of these people"101.

Thus, the Polish-Lithuanian topic became one of the key elements of the French discourse throughout the era of Biedermeire. The French press viewed Poland as an integral part of the European family, which might have become a new "window to Europe" for Russia in the first years after the Congress of Vienna. However, in the course of time the Poles became the symbol of a nation oppressed by the Russian state. All this exerted strong influence on the public thought of Russia. Russian intellectuals perceived this theme using the categories and the language of the French publicists. The approval or rejection of the published viewpoints shaped the tendencies of the discussions and debates. Hence, focusing on this subject provides a clear insight into the views of the Russian educated class on the Polish-Lithuanian issues.

\section{References}

Angran P. Echoes of the Decembrist Uprising in France. Voprosy istorii, 1952, no. 12, pp. 98-116. (In Russian) Askenazy Sh. Congress of Poland (1815-1830). Moscow, Knigoizdatel'stvo pisatelei Publ., 1915, 168 p. (In Russian)

Belousov M. S. Moscow Conspiracy of the Decembrists. Vestnik of Saint Petersburg University. History, 2018, vol. 63 , iss. 1 , pp. $29-40$.

98 Delo kniazia S. P. Trubetskogo // Vosstanie dekabristov: materialy po istorii vosstaniia dekabristov. Vol. 1. Moscow; Leningrad, 1925. P. 15.

99 Zapiski S. P. Trubetskogo // Trubetskoi S. P.Zapiski. Pis'ma I. N. Tolstomu. 181-1823 gg. St. Petersburg, 2011. P. 62-63.

100 Kotov A. E. Mikhail Iuzefovich — ideolog russkogo politicheskogo predmoderna // Voprosy istorii. 2018. No. 6. P. 113.

${ }^{101}$ Potapova N.D. Tribuny syrykh kazematov. Politika i diskursivnye strategii v dele dekabristov. P. 18. 
Belousov M.S. Disputes about Speaking from their Cells. Vestnik of Saint Petersburg University. History, 2019, vol. 64, iss. 3, pp. 1160-1173. (In Russian)

Black J.L. Nicholas Karamzin's “Opinion” on Poland: 1819. The International History Review, 1981, vol. 3, no. 1, pp. 1-19.

Blackwell W. L. Russian Decembrist views of Poland. The Polish Review, 1958, vol. 3, no. 4, pp. 30-54.

Burckhardt M. Vom Geist der Maschine. Eine Geschichte kultureller Umbrüche. Frankfurt; New York, Campus-Verlag, 1999, 409 s.

Capelle B., Demory J.-C. Maréchaux d'Empire. Paris, Le Chene, 2008, 287 p.

Caton A. Th. Disenchantment during the Biedermeir period: political subtexts in Schubert's songs: PhD Thesis. Cardiff, 2011.

Chernov K. S. "State Charter of the Russian Empire" (on the Issue of Russian Constitutionalism): dis. ... kand. ist. nauk. Moscow, 2007, 307 p. (In Russian)

Davydov M. V. Opposition of his Majesty. Moscow, RGGU Press, 1994. 189 p. (In Russian)

Flynn J.T. Uvarov and the "Western Provinces": A Study of Russia's Polish Problem. The Slavonic and East European Review, 1986, vol. 64, no. 2, pp. 212-236.

Foucault M. Intellectuals and Power: Selected Political Articles, Speeches, and Interviews. Moscow, Praksis Publ., 2002, 384 p. (In Russian)

Hetnal A. A. The Polish Right and The Question of National Independence in Russian Poland (1815-31). The Case of General Augustyn Słubicki. The Polish Review, 1986, vol. 31, no. 1, pp. 13-25.

Kotov A.E. Mikhail Yuzefovich - ideologist of the Russian political pre-modern. Voprosy istorii, 2018, no. 6 , pp. $105-121$.

Laclau E., Mouffe Ch. Hegemony and socialist strategy. London; New York, Verso, 2001, 198 p.

Liubeznikov O. A. Russian Texts of the Polish Constitution of 1815: Translations and Place in Historiography. Mavrodinskie chteniia - 2018. Materialy Vserossiiskoi nauchnoi konferentsii, posviashchennoi 110-letiiu so dnia rozhdeniia professora Vladimira Vasilevicha Mavrodina. St. Petersburg, Nestor-istoriia Publ., 2018, pp. 256-259. (In Russian)

Mazour A.G. First Russian revolution 1825. The Decembrist movement. Its origins, development and significance. Stanford, California, Stanford University Press, 1937, 342 p.

Mironenko S. V. Autocracy and Reform. Political Struggle in Russia at the beginning of the $19^{\text {th }}$ Century. Moscow, Nauka Publ., 1989, 240 p. (In Russian)

Morley Ch. Alexander I and Czartoryski: The Polish Question from 1801 to 1813. The Slavonic and East European Review. 1947, vol. 25, no. 65, pp. 405-426.

Morley Ch. Czartoryski as a Polish Statesman. Slavic Review, 1971, vol. 30, no. 3, pp. 606-614.

Nechkina M.V. Griboedov and the Decembrists. Moscow, Izdatel'stvo AN SSSR Publ., 1951, 626 p. (In Russian)

Nechkina M.V. The Movement of the Decembrists. Vol.1. Moscow, Izdatel'stvo Akademii nauk SSSR Publ., 1955, 481 p. (In Russian)

Okun' S. B. Russian History. 1796-1825. Leningrad, Izdatel'stvo Leningradskogo gosudarstvennogo ordena Lenina universiteta Publ., 1947, 191 p. (In Russian)

Ol'shanskii P. Decembrists and the Polish National Liberation Movement. Moscow, Izdatel'stvo sotsial'noekonomicheskoi literatury Publ., 1959, 226 p. (In Russian)

Pasquer É.-D. Mémoires du chancelier Pasquier: histoire de mon temps. T.4. Paris, E. Plon, Nourrit, 1893, $485 \mathrm{p}$.

Parsamov V.S. Decembrists and French Liberalism. Moscow, Polimed Publ., 2001, 240 p. (In Russian)

Potapova N. D. Speaking from their Cells: Discourse and Political Strategies of the Decemberists. St. Petersburg, European University at Saint Petersburg Press, 2017, 416 p. (In Russian)

Shil'der N. K. Emperor Alexander the First. His Life and Reign. Vol.3. St. Petersburg, izdanie A. S. Suvorina, 1897,569 p. (In Russian)

Shchegolev S. I. Alexander I and the Polish Constitution of 1815. Trudy kafedry istorii Novogo i Noveishego vremeni. St. Petersburg, 2014, no. 12, pp. 79-87. (In Russian)

Shul'gin V.N. Russian Free Conservatism of the first half of the $19^{\text {th }}$ Century. St. Petersburg, Nestor-istoriia Publ., 2009, 496 p. (In Russian)

Solov'ev S. M. Congress of Vienna. Russkii vestnik, 1865, vol. 55, no. 2, pp. 375-438. (In Russian)

Solodovnikova T. Yu. Charles Baudelaire and the Formation of Literary and Artistic Journalism in France: The first half - the Middle of the XIX century: Diss. ... kand. filol. nauk. Krasnodar, 2000, 155 p. (In Russian)

Stepanov M. A. Hardware Understanding of Media. Vestnik Leningradskogo gosudarstvennogo universiteta im. A. S. Pushkina, 2010, vol. 2, iss. 3, pp. 184-200. (In Russian) 
Timoshchuk V. Alexander I and the Polish Question at the Vienna Congress. According to Documents of Vienna Secret Police Agents. Russkaia starina, 1914, vol. 157, no. 1, pp. 135-145. (In Russian)

Thackeray F. W. N. N. Novosil'tsov, The Polish Years. The Polish Review, 1983, vol. 28, no. 1, pp. 32-46.

Wallerstein I. After Liberalism. Moscow, Editorial Publ., 2003, 256 p. (In Russian)

Valette R. M. Benjamin Constant, Dramatic Theorist. The French Review, 1964, vol. 37, pp. 426-431.

Walker F. A. Poland in the Decembrists' Strategy of Revolution. The Polish Review, 1970, vol. 15, no. 2, pp. $43-54$.

Webster C. The congress of Vienna (1814-1815). London, H. M. Stationery Office, 1920, 174 p.

Zawadzki W. H. Russia and the Re-Opening of the Polish Question, 1801-1814. The International History Review, 1985, vol. 7, no. 1, pp. 19-44.

Received: June 4, 2019

Accepted: September 9, 2019

Статья поступила в редакцию 4 июня 2019 г. Рекомендована в печать 9 сентября 2019 г. 